\title{
Specific Changes in the Basement Membrane of the Proximal Tubules in the Murine Polycystic Kidney Detected by the Novel Anti-basement Membrane Monoclonal Antibody D28
}

\author{
Shizuko NAGAO, Yoh-ichi KOYAMA*,**, and Hisahide TAKAHASHI \\ Laboratory Animal Center, ${ }^{*}$ Division of Cell Biology, Institute for Comprehensive \\ Medical Science, Fujita Health University, 1-98 Dengakugakubo, Kutsukake-cho, \\ Toyoake-shi, Aichi 470-11, Japan
}

(Received 25 March 1994/Accepted 31 May 1994)

\begin{abstract}
In order to analyze renal abnormalities in mice with polycystic kidney disease (PKD), we produced a series of monoclonal antibodies reactive with the murine kidney by hybridizing P3U1 myeloma cells with spleen cells from DBA/2 mice immunized with the kidney of adult-type PKD mice, DBA/2FG-pcy. One clone, D28, reacted specifically with the basement membrane of the proximal tubules of $\mathrm{DBA} / 2$ mice and $\mathrm{DBA} / 2 \mathrm{FG}-p c y$ mice. It did not react with other parts of the murine kidney nor with other tissues such as the skin, ovary, fallopian tube, testis, lung and small intestine. While other components such as collagen IV, laminin and the core protein of proteoglycan could be found, the D28 epitope could not be found in the basement membrane of renal cysts formed in adult-type (DBA/ $2 \mathrm{FG}-p c y)$ and infant-type (C57BL/6J-cpk) PKD mice. The D28 epitope did not, however, disappear from the basement membrane of proximal tubules in other types of renal abnormalities. These results suggest that the formation of renal cysts in the proximal tubules is associated with an alteration to the proximal tubule-specific structure of the basement membrane. The D28 monoclonal antibody should prove a useful tool with which to analyze basement membrane-associated abnormalities in genetic PKD.-KEY WORDS : basement membrane, monoclonal antibody, mouse, polycystic kidney
\end{abstract}

Human hereditary polycystic kidney disease (PKD) is a disorder caused by an autosomal recessive (infant-type) or dominant mutation (adult-type) and characterized by the progressive enlargement of the kidneys, which become filled with numerous expanding cysts [14]. A renal cyst is formed by dilation of the nephron and the collecting ducts [10] and it may be the result of an abnormal susceptibility to the epidermal growth factor (EGF) or the transforming growth factor $\beta$ (TGF- $\beta$ ) $[31,33]$, a high expression of the $c-e r b-2$ oncogene [18], an altered localization of $\mathrm{Na}^{+}$, $\mathrm{K}^{+}$-ATPase $[33,34]$, or changes in the turnover or the expression of basement membrane (BM) components [32]. However, precise mechanisms of the renal abnormalities in PKD remain unclear.
Several animal models of human PKD have been studied. A murine model of infant-type $\mathrm{PKD}$, the $\mathrm{C} 57 \mathrm{BL} / 6 \mathrm{~J}-c p k \quad(\mathrm{~B} 6-c p k)$ mouse strain, carries an autosomal recessive mutation on chromosome 12 [7]. B6-cpk mice have abnormalities in the expression of the $\mathrm{BM}$ components [8], preproEGF mRNA [11], sulfated glycoprotein-2 [16], some oncogenes $[6,17]$ and $\mathrm{Na}^{+}, \mathrm{K}^{+}-\mathrm{ATPase}[2]$. Takahashi et al. $[26,27]$ presented an adult-type murine model of PKD, DBA/2FG-pcy (D2-pcy) mouse strain, which carries the mutant gene, $p c y$, in the genetic background of DBA/2 (D2) mouse. Pathogenesis caused by the $p c y$ gene is influenced by the genetic background, and renal abnormalities are far more severe in D2-pcy mice than in C57BL/6FG-pcy mice [23]. The Han:SPRD rat is another animal model of PKD

**Present address : Nippi Research Institute of Biomatrix, 1-1 Senju-Midori-cho, Adachi-ku, Tokyo 120, Japan 
and is remarkable in that the homozygous mutant rats exhibit infant-type PKD while the heterozygous animals display an adult-type PKD phenotype [22].

For this study, we produced a series of anti-kidney monoclonal antibodies (mAbs) and carried out an immunohistochemical analyses of the abnormalities in the renal basement membrane of PKD mice. We show that the BM of the proximal tubules contains a highly specific epitope which is detected by the novel $\mathrm{mAb}$ but disappears upon the formation of renal cysts.

\section{Materials and Methods}

Animals : Production of the D2-pcy mice has elsewhere been described $[23,26,27]$. B6$c p k$ mice [12] and NC mice [28] were obtained from Drs. Grantham and Gattone (University of Kansas Medical Center, U.S.A.) and from Dr. Kondo (Nagoya University, Japan). Daunomycin was i.v. injected into 8-week-old D2 mice at $20 \mathrm{mg} / \mathrm{kg}$ body weight and the mice were sacrificed 20 days after the treatment.

Production of anti-kidney mAbs : Two series of immunization were carried out to produce anti-kidney mAbs; both D2 and D2pcy mice were immunized with kidney from 1day-old mice of the counterpart strain by subcutaneous injection of homogenized kidney mixed with Freund's complete adjuvant. Every 28 days for the next 6 months the mice were then given subcutaneous injections of kidney homogenate mixed with Freund's incomplete adjuvant. Production of anti-kidney $\mathrm{mAb}$ was monitored by indirect immunofluorescence staining of frozen sections of kidney from 1day-old mice. Dissociated spleen cells from immunized mice were fused with P3U1 myeloma cells by a standard method employing polyethylene glycol. Ascites were obtained from $\mathrm{BALB} / \mathrm{c}-n u / n u$ mice, which were intraperitoneally inoculated with hybridoma cells. Class and subclass of the mAbs were determined with an Ouchterlony double diffusion test.

Immunohistochemical staining : Kidneys were obtained from D2 and D2- $p c y$ mice at 1 day, 3 and 8 weeks of age and from $\mathrm{B} 6{ }^{-} c p k$ mice at 1,2 and 3 weeks of age. Eight-weekold D2 mice were the source of other tissues such as the lung, small intestine, skin, ovary, fallopian tube and testis. Tissue fragments were embedded in O.C.T. compound, and 6$\mu \mathrm{m}$-thick frozen sections were cut. After being fixed in ethanol, the sections were allowed to react overnight at $4^{\circ} \mathrm{C}$ either with the D28 ascites diluted to $1 / 500$ with phosphate-buffered saline containing $1 \%$ bovine serum albumin (PBS/BSA) or with an isotype-matched control anti-Thy-1.1 mAb (Serotec, Kidlingston, Oxford) diluted to $1 / 200$ with PBS/BSA. In order to detect $\mathrm{BM}$ components, frozen sections were first treated with anti-collagen IV rabbit antiserum (LSL, Nerima, Tokyo), anti -laminin rabbit antiserum (LSL), or anti-core protein of heparan sulfate proteoglycan (HSPG) rabbit antiserum (a kind gift from Dr. Yamada, National Institute of Health, Bethes$\mathrm{da}, \mathrm{MD})$. Then thin sections were treated with fluorescein isothiocyanate (FITC)-conjugated goat IgG anti-mouse IgM (Cappel, Weat Chester, Pennsylvania), which was used as a second antibody. Normal rabbit serum was used as a negative control.

The precise location of the D28 epitope in the kidney was determined by double-staining sections with the D28 ascites as described above and with either rhodamine-conjugated Lotus tetragonolobus (LTA) lectin (E-Y Laboratories, San Mateo, California), rhodaminelabeled Peanut agglutinin (PNA) lectin (E-Y Laboratories), or rhodamine-labeled Dolichos biflorus agglutinin (DBA) lectin (E-Y Laboratories). LTA lectin binds specifically to the proximal tubules, PNA lectin to the distal tubules and collecting ducts, and DBA lectin only to the collecting ducts of the murine kidney $[9,19]$.

\section{Results}

The D28 mAb detects a specific epitope found in the BM of the proximal tubules: In 1-dayold D2 mice, only the proximal tubules but not the distal tubules and the collecting ducts of the kidney were found to be dilated. In older D2 mice, 3 and 8 weeks of age, no dilation was found in any region of the tubules nor the collecting ducts. One of the anti-kidney mAbs, D28, produced from spleen cells of immunized D2 mice reacted with the $\mathrm{BM}$ of at least some renal tubules in mice of all ages while it did not bind to any other parts of the kidney such as the Bowman's capsule, loop of Henle, or collecting 
Table 1. The distribution of the D28 epitope in the tubular $\mathrm{BM}$ of $\mathrm{D} 2, \mathrm{~B} 6, \mathrm{D} 2-p c y$ and $\mathrm{B} 6-c p k$ mice

\begin{tabular}{|c|c|c|c|}
\hline strain & age region & $\begin{array}{l}\text { proximal region } \\
\text { (LTA-positive) }\end{array}$ & $\begin{array}{c}\text { distal region } \\
\text { (PNA- or DBA-positive) }\end{array}$ \\
\hline $\mathrm{D} 2$ and $\mathrm{B} 6$ & $\begin{array}{c}\text { the examined } \\
\text { all ages }\end{array}$ & + & - \\
\hline \multirow{3}{*}{$\mathrm{D} 2-p c y$} & 1-day & + & - \\
\hline & 3-week & + & - \\
\hline & 8-week & - & - \\
\hline \multirow{3}{*}{$\mathrm{B} 6-c p k$} & 1-week & \pm & - \\
\hline & 2-week & - & - \\
\hline & 3-week & - & - \\
\hline
\end{tabular}

ducts. Three BM components, collagen IV, laminin, and the core protein of HSPG, were detected in the BM of all tubules, as well as in the collecting ducts, Bowman's capsules, mesangial matrix and the capillary walls of glomeruli (not shown). The control mAb against the subclass, anti-Thy $1.1 \mathrm{IgM}$, bound to only intraglomerular $\mathrm{BM}$ but did not react with tubules and vessels (not shown). In order to determine the precise location of the D28 epitope in the tubules, double-staining was carried out on frozen sections of the kidney employing the D28 $\mathrm{mAb}$ and either LTA, PNA or DBA lectin. As shown in Fig. 1 for 8week-old mice, the $\mathrm{D} 28 \mathrm{mAb}$ bound to the $\mathrm{BM}$ of all LTA-positive proximal tubules (Figs. 1 A, B) but not to any PNA-positive distal tubules (Figs. 1 C, D) or DBA-positive collecting ducts. This staining pattern occurred in mice of all ages, and it demonstrated that the $\mathrm{D} 28 \mathrm{mAb}$ binds specifically to the $\mathrm{BM}$ of the proximal tubules in the kidney.

We then examined the tissue distribution of the D28 epitope in 8 -week-old D2 mice. The three BM components were detected in the BM of the skin, ovary, fallopian tube, testis, lung and small intestine (not shown). However, the $\mathrm{D} 28 \mathrm{mAb}$ did not react with these tissues, nor did it react with rat kidney (not shown). These findings show that the $\mathrm{D} 28 \mathrm{mAb}$ recognizes an epitope in the BM of the proximal tubules that is specific to the above described region of the tissue of special species.

Distribution of the D28 epitope in the kidney of adult-type PKD mice : In 1-day-old D2pcy mice, segmental dilation was found in the DBA-positive collecting ducts and also in the tubular regions, the LTA-positive proximal and the PNA-positive distal region. The distribution of the D28 epitope was the same between $\mathrm{D} 2$ and D2-pcy mice ; it was found in the BM of the proximal tubules, which were identified by the presence of LTA-binding sites (Figs. $2 \mathrm{~A}$, $\mathrm{B})$ and the absence of PNA-binding sites (Figs. $2 \mathrm{C}, \mathrm{D}$ ) and DBA-binding sites (not shown).

In 3-week-old D2-pcy mice, renal tubules were more enlarged than in 1-day-old mice. The D28 mAb bound only to some of the BM of the proximal tubules, which were again LTApositive (Figs. $3 \mathrm{~A}, \mathrm{~B}$ ) and PNA-negative (Figs. $3 \mathrm{C}, \mathrm{D}$ ) and DBA-negative (not shown). The D28 mAb bound to some of the $\mathrm{BM}$ of the proximal tubules, which were again LTA-positive (Figs. $3 \mathrm{~A}, \mathrm{~B}$ ) and PNA- and DBA-negative (not shown) but not to the tubular $\mathrm{BM}$ of the distal region, PNA-(Figs. $3 \mathrm{C}$, D) and DBA-positive (not shown).

In 8-week-old D2-pcy mice, numerous large renal cysts were found, and some Bowman's capsules had also become enlarged. It was difficult to identify the origin of these cysts because none of them bound LTA lectin while some of them bound PNA lectin and DBA lectin. Although the epithelial cells of the cysts were flatter than those of normal tubules, the three BM components, collagen IV, laminin and the core protein of HSPG, mentioned above were detected in the $\mathrm{BM}$ of the large cysts by specific antibodies (Figs. $4 \mathrm{~A}, \mathrm{~B}, \mathrm{C}$ ) . The D28 epitope (Fig. $4 \mathrm{D}$ ) could not be detected in the BM which were supposed to be the proximal tubules since these larger cysts did not react with PNA lectin and DBA lectin (not 
shown). We concluded that the distribution of the D28 epitope along the tubules was not altered by the $p c y$ mutation and, in particular, that the epitope disappears from the BM of the bigger cysts.

Distribution of the D28 epitope in the kidney of infant-type PKD mice : In B6-cpk mice, cyst formation starts before birth in the proximal tubules, and numerous cysts emerging from proximal tubules and collecting ducts were found in 1-, 2- and 3-week-old mice [12]. Distribution of the D28 epitope in the kidney of B6-cpk mice was essentially the same as in D2 and D2-pcy mice (not shown). The reactivity to the $\mathrm{D} 28 \mathrm{mAb}$ was already reduced in the LTA-postitive proximal cysts of 1-week -old B6-cpk mice (not shown), but almost completely lost in those of 2-and 3-week-old mice (Figs. $5 \mathrm{~A}, \mathrm{~B}$ ) while collagen IV, laminin and HSPG were present in the BM of the cysts of mice of all ages (not shown). Then the D28 epitope never be observed in the BM of either PNA-positive (Figs. 5 C, D) or DBA-positive (not shown) cysts.

Distribution of the D28 epitope in the kidney of mice with other renal abnormalities: We studied the distribution of the D28 epitope in the kidney of Daunomycin-treated mice to see whether its disappearance was specific to expanding cysts. As had been reported on rats [15], treatment with Daunomycin resulted in a dilation of the collecting ducts and the tubules in both the proximal and the distal region (not shown). The D28 epitope persisted in the BM of the dilated proximal tubules whereas the PNA-positive distal tubules did not react with the D28 mAb (not shown). The D28 epitope was also found with its usual distribution pattern in the kidney of NC mice in which deposits of the immune complexes are present in the glomeruli (not shown).

\section{Discussion}

The BM of the kidney has several important functions: it is an adhesive substrate in the glomeruli and tubules, plays a pivotal role in embryonic development and organogenesis of the kidney and is involved in permselective functions [1].

Befitting the complex structure and function of the kidney, the composition of the renal $\mathrm{BM}$ is heterogeneous and has been identified with the help of specific monoclonal and polyclonal antibodies $[1,30]$. Among these mAbs and polyclonal antibodies, the LAM-2 [21] and Lam-2 [20] mAbs, the 3M-1glycoprotein polyclonal antibody $[5,24]$, and our novel D28 $\mathrm{mAb}$ have a similar specificity in that they do not react with the $\mathrm{BM}$ of the distal tubules. Unlike the other antibodies, however, the D28 mAb does not react with the $\mathrm{BM}$ of the Bowman's capsule $[5,20,21,24]$. It is therefore highly specific to BM of the proximal tubules. Thus, the $\mathrm{D} 28 \mathrm{mAb}$ revealed the unique BM structure of the proximal tubules.

The formation of renal cysts is accompanied by increased epithelial cell proliferation and altered transtubular fluid transport $[13,14]$. BM abnormalities play an important role in cyst formation and bring forth changes in the functioning of the kidney. An increased turnover and a decrease in HSPG was observed in the renal $\mathrm{BM}$ of $\mathrm{PKD}$ patients and druginduced $\mathrm{PKD}$ rats $[3,4,32]$. In infant-type $\mathrm{PKD}$ mice, $\mathrm{B} 6-c p k$, abnomalities of the $\mathrm{BM}$ in the cyst were found $[8,12,25]$. The gene expression of collagen IV and laminin seemed likewise abnormal [8]. We showed that the D28 epitope, which is the specific structure in the $\mathrm{BM}$ of the proximal tubule, disappears from that of the cysts as they grow bigger although BM components such as collagen IV, laminin and proteoglycan do not disappear. Our results provide further evidence that the formation of cysts is accompanied by a structural change in the BM, particularly in the proximal region of the tubules. These changes in D28 epitope and components occur similarly in the two murine models of PKD, B6-cpk and D2-pcy. Our study also showed that the D28 $\mathrm{mAb}$ detected in the $\mathrm{BM}$ structure was specific to the formation of cysts, as the D28 epitope did not disappear from the tubules even when they became dilated through the drug treatment. The solubulized BM components, collagen IV and laminin, did not contain the D28 epitope since an enzyme-linked immunosorbent assay could not demonstrate a specific binding of the D28 mAb to these molecules. Although the exact molecular change is not clear at present, the cyst-related change in the BM of the proximal tubules seems to be specifically localized, since the adjoining $\mathrm{BM}$ remained positive for the $\mathrm{D} 28$ epitope. The $\mathrm{D} 28 \mathrm{mAb}$ will be a useful tool to investigate the cause and the 
process of renal cyst formation in the mouse.

The authors gratefully acknowledge the technical contributions of Noboru Ogiso. This work was supported in part by two grands-in-aid for scientific research from Fujita Health University and from the Ministry of Education, Science and Culture of Japan.

\section{References}

[1] Abrahamson, D. R. and Leardkamolkarn, V. (1991). Development of kidney tubular basement membranes. Kidney Int., 39, 382-393.

[2] Avner, E. D., Sweeney, Jr. W. E., and Nelson, W. J. (1992) . Abnormal sodium pump distribution during renal tubulogenesis in congenital murine polycystic kidney disease. Proc. Natl. Acad. Sci. USA, 89, 7447-7451.

[3] Carone, F. A. (1988) . Functional changes in polycystic kidney disease are tubulo-interstitial in origin. Semin. Nephrol., 8, 89-93.

[4] Carone, F. A., Makino, H., and Kanwar, Y. S. (1998). Basement membrane antigens in renal polycystic disease. Am. J. Pathol., 130, 466-471.

[5] Clayman, M. D., Martinez-Hernandez, A., Michaud, L., Alper, R., Mann, R., Kefalides, N. A., and Neilson, E. (1985). Isolation and characterization of the nephritogenic antigen producing anti-tubular basement membrane disease. J. Exp. Med ., 161, 290-305.

[6] Cowley, Jr. B. D., Chadwick, L. J., Grantham, J. J., and Calvet, J. P. (1991). Elevated proto-oncogene expression in polycystic kidneys of the C57BL/ 6J (cpk) mouse. J. Am. Soc. Nephrol., 1, 1,0481,053 .

[ 7] Davisson, M. T., Guay-Woodford, L. M., Harris, H. W., and D'Eustachio, P. (1991). The mouse polycystic kidney disease mutation $(c p k)$ is located on proximal chromosome 12. Genomics, 9, 778-781.

[8] Ebihara, I., Killen, P. D., Laurie, G. W., Huang, T., Yamada, Y., Martin, G. R., and Brown, K. S. (1988). Altered mRNA expression of basement membrane components in a murine model of polycystic kidney disease. Lab. Invest., 58, 262-269.

[9] Faraggiana, T., Malchiodi, F., Prado, A., and Churg, J. (1982). Lectin-peroxidase conjugate reactivity in normal human kidney. J. Histochem. Cytochem., 30, 451-458.

[10] Gagnadoux, M., Habib, R., Levy, M., Brunelle, F., and Broyer, M. (1989). Cystic renal disease in children. Adv. Nephrol., 18, 33-58.

[11] Gattone II, V. H., Andrews, G. K., Fu-Wen, N., Chadwick, L. J., Klein, R. M., and Calvet, J. P. (1990). Defective epidermal growth factor gene expression in mice with polycystic kidney disease. Dev. Biol., 138, 225-230.

[12] Gattone II, V. H., Calvet, J. P., Cowley, Jr. B. D., Evan, A. P., Shaver, T. S., Helmstadter, K., and Grantham, J. J. (1988). Autosomal recessive polycystic kidney disease in a murine model. Lab. Invest., 59, 231-238.

[13] Grantham, J. J. (1992). Polycystic kidney disease Etiology and pathogenesis. Hosp. Pract., 27, 51-59.

[14] Grantham, J. J. (1990). Polycystic kidney disease: neoplasia in disguise. Am.J. Kidney. Dis., 15, 110-
116

[15] Grone, H., Weber, K., Grone, E., Helmchen, U., and Osborn, M. (1987). Coexpression of keratin and vimentin in damaged and regenerating tubular epithelia of the kidney. Am. J. Pathol., 129, 1-8.

[16] Harding, M. A, Chadwick, L. J., Gattone II, V. H., and Calvet, J. P. (1991). The SGP-2 gene is developmentally regulated in the mouse kidney and abnormally expressed in collecting duct cysts in polycystic kidney disease. Dev. Biol., 146, 483-490.

[17] Harding, M. A., Gattone II, V. H., Grantham, J. J., and Calvet, J. P. (1992) . Localization of overexpressed $c$-myc mRNA in polycystic kidneys of the $c p k$ mouse. Kidney Int . , 41, 317-325.

[18] Herrera, G. A. (1991). C-erb B-2 amplification in cystic renal disease. Kidney Int., 40, 509-513.

[19] Holthofer, H. (1983). Lectin binding sites in kidney : a comparative study of 14 animal species. J. Histochem. Cytochem., 31, 531-537.

[20] Horikoshi, S., Koide, H., and Shirai, T. (1988). Monoclonal antibodies against laminin A chain and $\mathrm{B}$ chain in the human and mouse kidneys. Lab. Invest., 58, 532-538.

[21] Jaffe, R., Bender, B., Santamaria, M., and Chung, A. E. (1984). Segmental staining of the murine nephron by monoclonal antibodies directed against the GP-2 subunit of laminin. Lab. Invest ., 51, 88-96.

[22] Kaspareit-Rittinghausen, J., Rapp, K., Deerberg, F., Wcislo, A., and Messow, C. (1989). Hereditary polycystic kidney disease associated with osteorenal syndrome in rats. Vet. Pathol., 26, 195-201.

[23] Nagao, S., Hibino, T., Koyama, Y., Marunouchi, T., Konishi, H., and Takahashi, H. (1991). Strain difference in expression of the adult-type polycystic kidney disease gene, pcy, in the mouse. Exp. Anim., 40, 45-53.

[24] Neilson, E., Sun, M., Kelly, C., Hines, W., Haverty, T., Clayman, M., and Cooke, N. (1991). Molecular caracterization of a major nephritogenic domain in the autoantigen of anti-tubular basement memrane disease. Proc. Natl. Acad. Sci. USA, 88, 2,0062,010 .

[25] Nidess, R., Koch, W. E., Fried, F. A., McFarland, E., and Mandell, J. (1984). Development of the embryonic murine kidney in normal and congenital polycystic kidney disease : characterization of a proximal tubular degenerative process as the first observ. able light microscopic defect. J. Urol., 131, 156-162.

[26] Takahashi, H., Calvet, J. P., Dittemore-Hoover, D., Yoshida, K., Grantham, J. J., and Gattone II, V. H. (1991). A hereditary model of slowly progressive polycystic kidney disease in the mouse. J. Am . Soc. Nephrol., 1, 980-989.

[27] Takahashi, H., Ueyama, Y., Hibino, T., Kuwahara, Y., Suzuki, S., Hioki, K., and Tamaoki, N. (1986). A new mouse model of genetically transmitted polycystic kidney disease. J. Urol., 135, 1,2801,283 .

[28] Sakai, N., Kondo, K., and Migita, S. (1977). Quantitative estimation of serum Ss level : changes upon the development of autoantibodies environment and acute inflammation in inbred mice. J . Exp. Med . , 47, 117-123.

[29] Sweeney, J.r W. E. and Avner, E. D. (1992) . Pathophysiology of renal tubular cyst formation in murine 
models of polycystic kidney disease. Contrib. $\mathrm{Ne}$. phrol., 97, 23-34.

[30] Weber, M. (1992). Basement membrane proteins. Kidney Int ., 41, 620-628.

[31] Wilson, P. D. and Burrow, C. R. (1992). Autosomal dominant polycystic kidney disease : cellular and molecular mechanisms of cyst formation. $A d v . N e$. phrol., 21, 125-142.

[32] Wilson, P. D., Hreniuk, D., and Gabow, P. A. (1992). Abnormal extracellular matrix and excessive growth of human adult polycystic kidney disease epithelia. J. Cell. Physiol., 150, 360-369.

[33] Wilson, P. D. and Sherwood, A. C. (1991) Tubulocystic epithelium. Kidney Int., 39, 450-463.

[34] Wilson, P. D., Sherwood, A. C., Palla, K., Du, J., Watson, R., and Norman, J. T. (1991). Reversed polarity of $\mathrm{Na}^{+}, \mathrm{K}^{+}$-ATPase : mislocation to apical plasma membranes in polycystic kidney disease epithelia. Am. J. Physiol., 260, F420-F430.

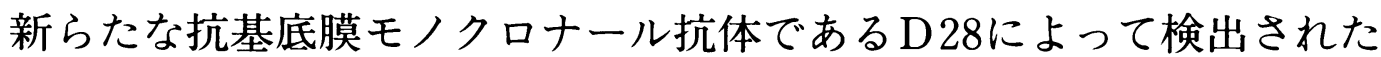 マウス多発性囊胞腎症の近位尿細管基底膜の特異的な変化
}

\author{
長尾静子・小山洋一**高橋久英 \\ 藤田保健衛生大学総合医科学研究所実験動物センター \\ *藤田保健衛生大学総合医科学研究所応用細胞研究部門
}

我々は，マウス多発性輁胞堅症（PKD）における堅 蔵の異常を解析するために, 成人型 PKD マウスである $\mathrm{DBA} / 2 \mathrm{FG}-p c y$ の腎窚を免度した DBA/2マウスから得 た脾成と, P3U1ミエローマ細胞を融合し，マウスの腎 婼に反応するモノクロナール抗体を作製した。得られ たクローンのひとつであるD28は，DBA/2マウスと $\mathrm{DBA} / 2 \mathrm{FG}-p c y$ マウスの近位尿細管基底膜に特異的に 反応した。しかし，D28抗体はマウスの堅㖑の他の部 位や, 皮虚, 卵巣, 卵管, 精巣, 肺および小腸等の腎 蔵以外の組織には, 反応しなかった。基底膜構成物質 であるコラーゲン IV，ラミニンおよびプロテオグリカ
ンのコア蛋白は，成人型PKDマウスである $\mathrm{DBA} / 2$ FG-pcy と乳幼児型 PKD マウスである C $57 \mathrm{BL} / 6 \mathrm{~J}-c p k$ に形成された腎旁胞の基底膜に，検出されたが, D28 エピトープは認められなかった。また，他の腎腸疾患 では，D28エピトープは近位尿細管基底膜から消失しな かった。これらの結果は，近位尿細管に形成される督 㐮胞が, 近位尿細管に特異的な構造の異常に関与する ことを示唆している。この様に，D28モノクロナール 抗体は, 遺伝性 PKDにおける基底膜に関連した異常を 解析するために有益な道具となるであろう。 


\section{Explanation of Figures}

Fig. 1. Location of the D28 epitope in the kidney of 8 -week-old D2 mice. Frozen sections were doublestained either with LTA lectin (A) and D28 $\mathrm{mAb}$ (B) or for PNA lectin (C) and D28 mAb (D). Arrows in (A) and (B) indicate the LTA-positive proximal tubules and arrowheads in (C) and (D) indicate the PNA-positive distal tubules.

Fig. 2. Location of the D28 epitope in the kidney of 1-day-old D2-pcy mice. Frozen sections were double-stained either with LTA lectin (A) and D28 $\mathrm{mAb}(\mathrm{B})$ or for PNA lectin (C) and D28 mAb (D) . In (A) and (B), arrows indicate LTA-positive proximal tubules. In (C) and (D), arrowheads indicate PNA-positive distal tubules, and asterisks indicate PNA-negative tubules.

Fig. 3. Location of the D28 epitope in the kidney of 3 -week-old D2- pcy mice. Frozen sections were double-stained either with LTA lectin (A) and D28
$\mathrm{mAb}(\mathrm{B})$ or for PNA lectin (C) and D28 mAb (D) . Arrows in (A) and (B) indicate the LTA-positive proximal tubules and arrowheads in (C) and (D) indicate the PNA-positive distal tubules.

Fig. 4. Indirect immunofluorescence staining of BM components in the kidney of 8-week-old D2-pcy mice. (A) collagen IV, (B) laminin, (C) core protein of HSPG, (D) D28. Arrows indicate the BM.

Fig. 5. Indirect immunofluorescence staining of the D28 epitope in the kidney of 2-week-old B6-cpk mice. Frozen sections were double-stained either with LTA lectin (A) and D28 mAb (B) or for PNA lectin (C) and D28 mAb (D). Arrows in (A) and (B) indicate the LTA-positive proximal tubules and arrowheads in (C) and (D) indicate the PNApositive distal tubules.
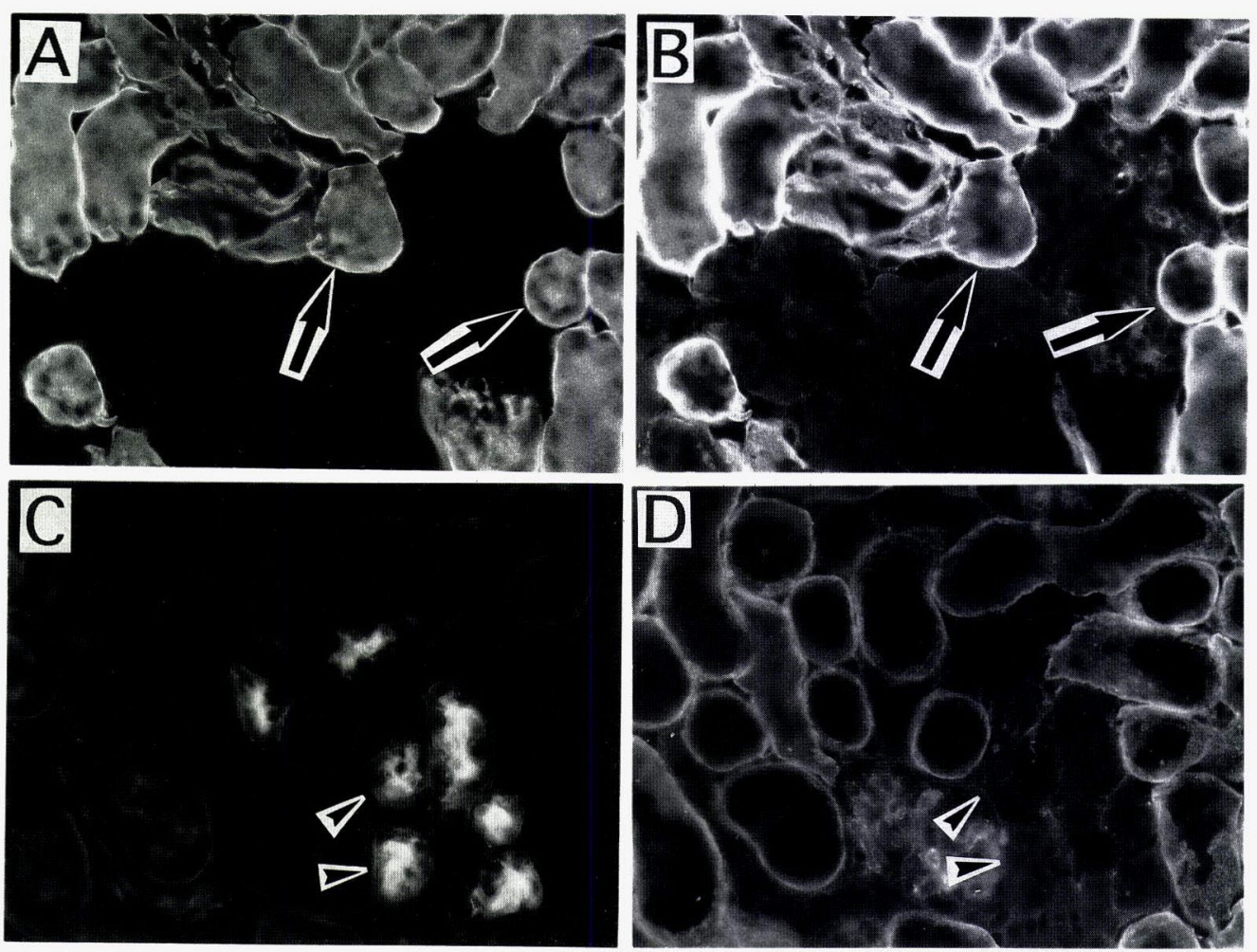

Fig. 1 . 

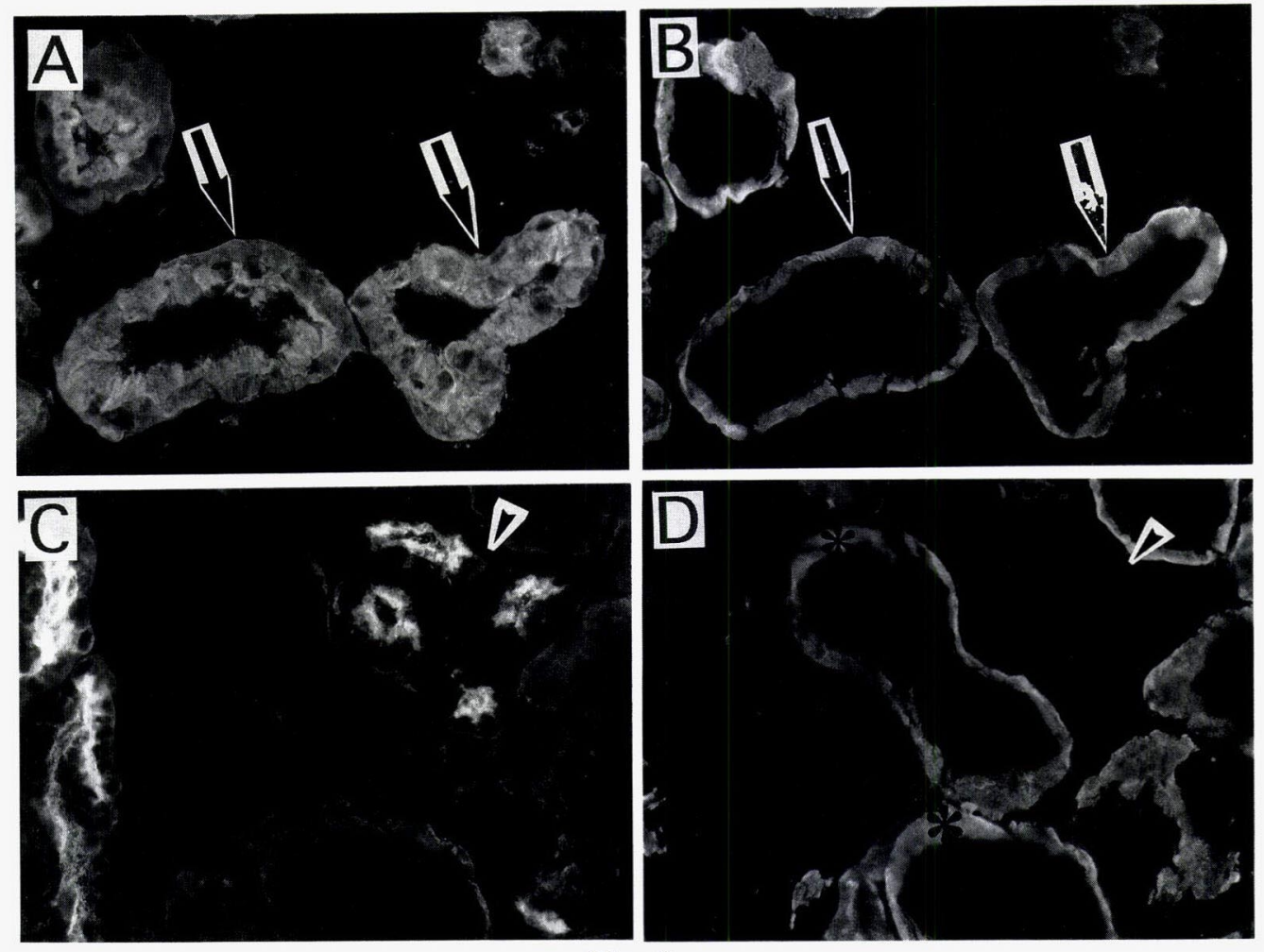

Fig. 2
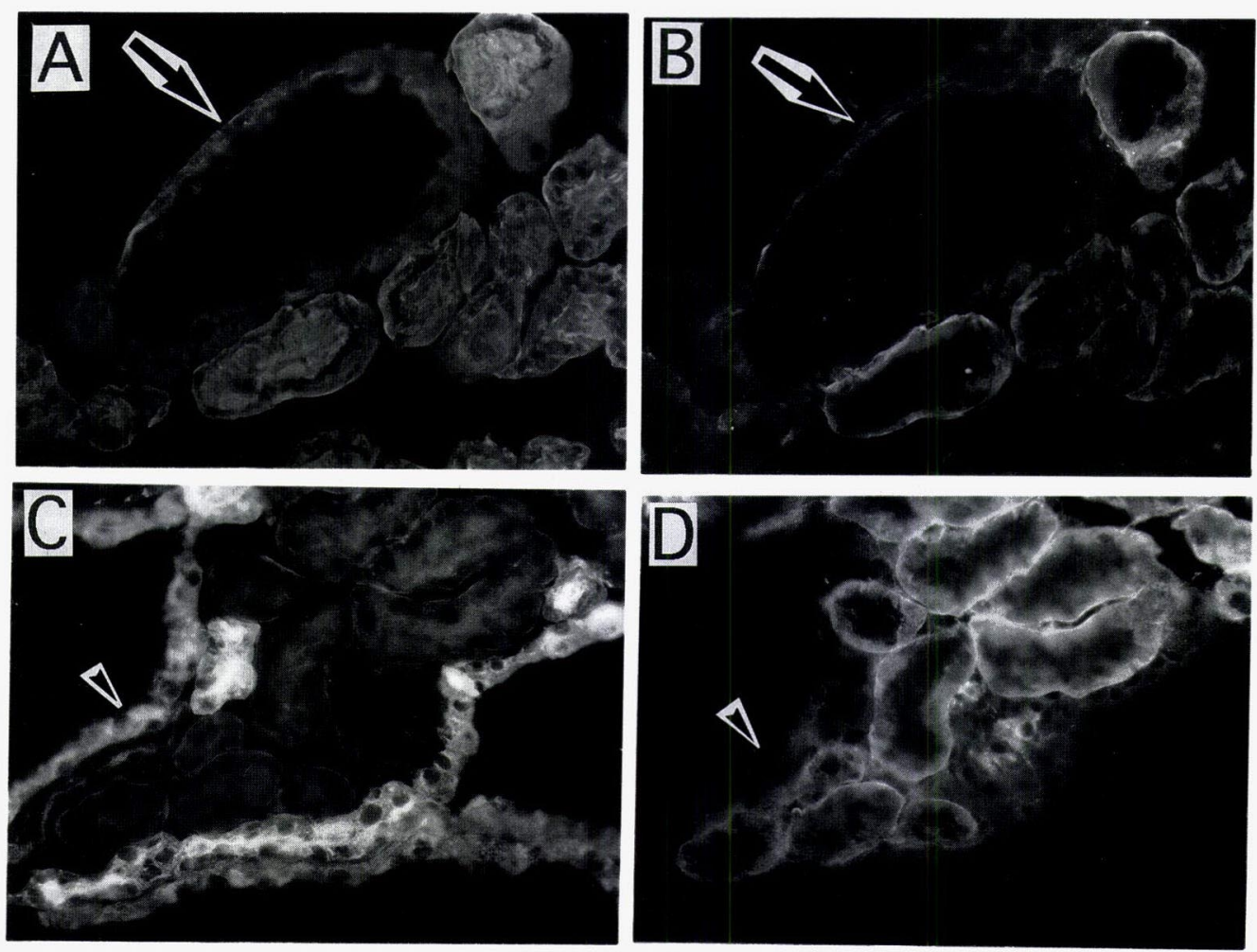

Fig. 3 

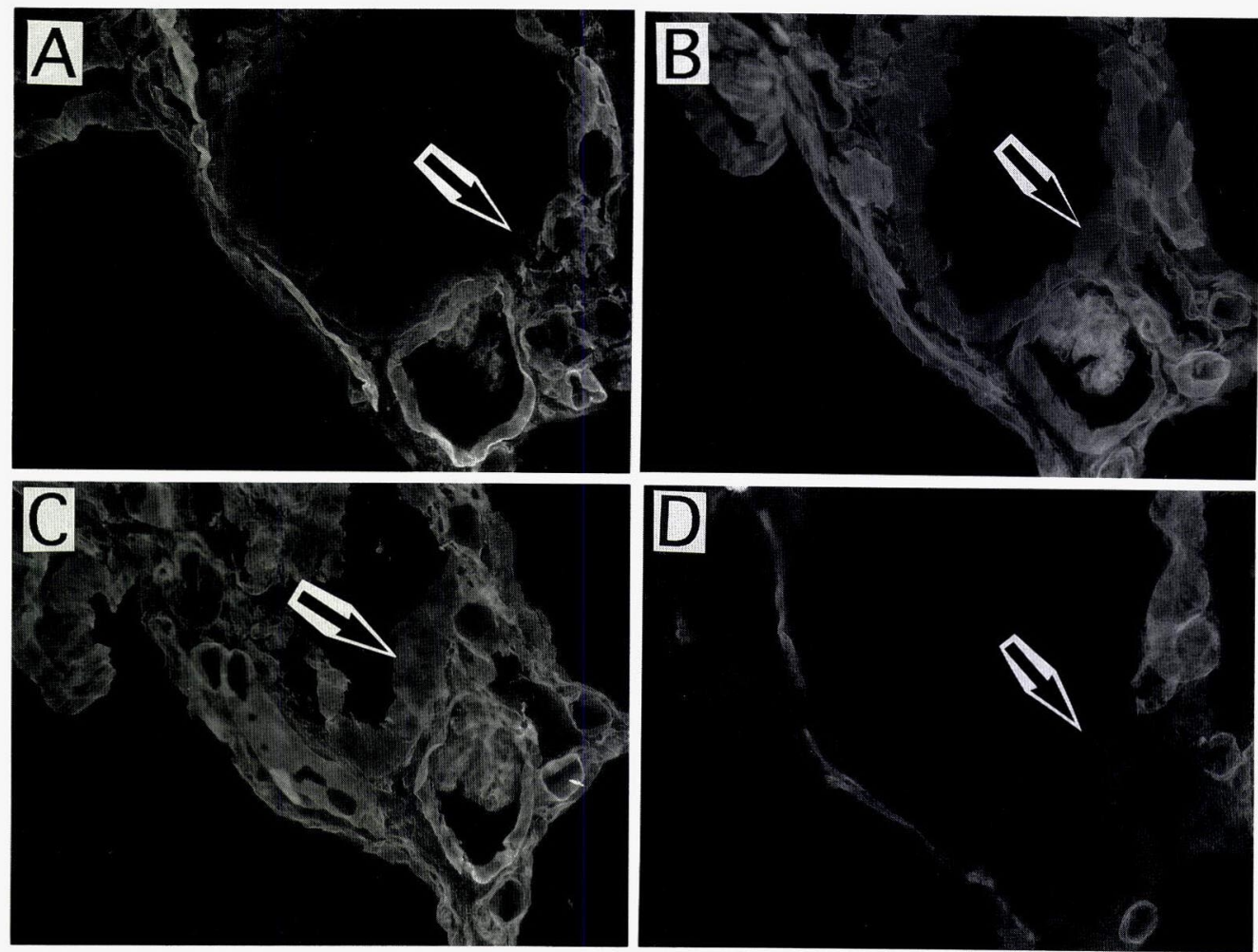

Fig. 4
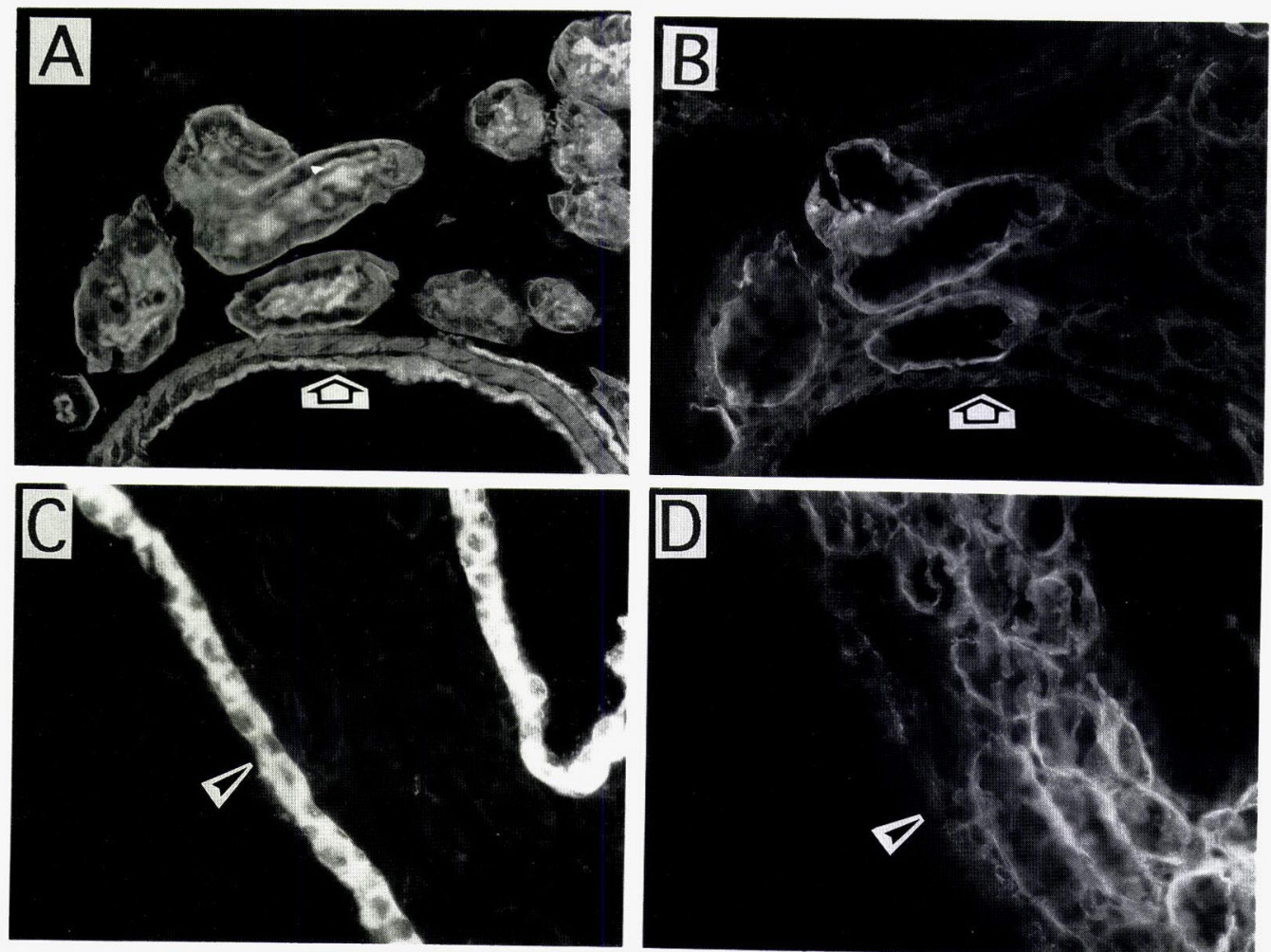

Fig. 5. 